\title{
Meat quality in an intergeneric factorial crossbreeding between muscovy (Cairina moschata) and Pekin (Anas platyrhynchos) ducks
}

\author{
Catherine LARZUL ${ }^{\mathrm{a} *}$, Benoit IMBERT $^{\mathrm{b}}$, Marie-Dominique BERNADET $^{\mathrm{c}}$, \\ Gérard GUY ${ }^{\mathrm{c}}$, Hervé RÉMIGNON ${ }^{\mathrm{b}}$
}

\author{
a Institut National de la Recherche Agronomique, Station d'Amélioration Génétique des Animaux, \\ BP 27, 31326 Castanet-Tolosan, France \\ ${ }^{\mathrm{b}}$ ENSAT-INP, Av. de l'Agrobiopole, BP 107, 31326 Castanet-Tolosan, France \\ ${ }^{\mathrm{c}}$ Institut National de la Recherche Agronomique, Station Expérimentale sur les Palmipèdes à Foie Gras, \\ 40280 Benquet, France
}

(Received 8 February 2005 - Accepted 2 February 2006)

\begin{abstract}
The characteristics of the breast meat were studied on force-fed male ducks resulting from a factorial crossbreeding between the muscovy and Pekin duck. The measurements were aimed at characterising the meat of these various genetic types and at describing their genetic parameters. Overall, 99 animals were measured. We measured the zootechnical performances of force-fed ducks as well as the physico-chemical, mechanical and biochemical characteristics of the pectoral muscle. The analyses showed that the effect of the genetic type was significant for the weight data; muscovy ducks were the heaviest, Pekin ducks the lightest, with the two other genetic types being intermediate. The weight of the liver was equal for muscovy and hinny ducks and higher in the mule duck. For growth traits, additive effects were significant with a higher growth rate for muscovy genes, and a large heterosis effect was observed for foie gras weight. For physico-chemical traits, significant genetic effects were few but the muscovy additive effect induced a lighter meat and a favourable heterosis effect was found for muscle $\mathrm{L}^{*}$ measured at 1 and 9 days post mortem. Muscle $\mathrm{pH}$ was influenced by additive effects, with a $\mathrm{pH}$ associated with muscovy genes. Finally, we remarked direct genetic effects estimated for textural properties that were favourable to the Pekin duck, which showed a more tender meat. In general, maternal effects were marginally significant.
\end{abstract}

\section{duck / force-feeding / meat quality / genetic parameters}

Résumé - Qualité de la viande de canards issus des croisements réciproques entre canard de Barbarie (Cairina moschata) et canard commun (Anas platyrhynchos). Les caractéristiques du magret ont été étudiées chez les canards mâles gavés issus d'un croisement factoriel entre le canard de Barbarie et le canard commun. Les mesures visaient à caractériser la viande de ces divers types

\footnotetext{
*Corresponding author: catherine.larzul@jouy.inra.fr
} 
génétiques et à en décrire les paramètres génétiques. Les performances zootechniques ainsi que les caractéristiques physico-chimiques, mécaniques et biochimiques du muscle pectoral de 99 canards gavés ont été mesurées. Les analyses ont montré que l'effet du type génétique était significatif pour les données de poids. Les canards de Barbarie étaient les plus lourds et les canards Pekin les plus légers, les deux types génétiques croisés étant intermédiaires. Le poids du foie était identique pour les canards de Barbarie et hinny et plus élevé pour le canard mulard. Pour les caractères de croissance, les effets additifs étaient significatifs avec une vitesse de croissance plus élevée pour les gènes Barbarie. Un effet d'hétérosis très élevé a été observé pour le poids du foie. Pour les caractères physico-chimiques, les effets génétiques significatifs sont peu nombreux mais on peut retenir des effets additifs significatifs pour la luminosité, les gènes Barbarie conduisant à une viande plus claire et un effet d'hétérosis favorable pour la valeur L* mesurée sur le muscle à 1 et 9 jours post mortem. Le pH musculaire est affecté par des effets additifs, le Barbarie induisant des $\mathrm{pH}$ plus faibles. Enfin, on retiendra des effets directs sur la texture de la viande, favorables au canard Pékin qui présente une viande plus tendre. D’une manière générale, les effets maternels étaient rarement significatifs.

canard / gavage / qualité de viande / paramètres génétiques

\section{INTRODUCTION}

Male mule ducks are bred in France mainly for foie gras production. However, in the last decade, there has been an increasing interest for meat from overfed ducks. Meat characteristics have been studied in muscovy, Pekin or mule ducks, sometimes with comparisons between several types of ducks ([1] for review). On the contrary, genetic influences have rarely been studied for meat characteristics in overfed ducks.

The mule duck is obtained by the crossbreeding of ducks from different genera: muscovy drakes (Cairina moschata) are mated to Pekin female ducks (Anas platyrhynchos) in order to produce mule ducks. The reciprocal mating produces hinny ducks. One study has established genetic parameters from the complete factorial crossbreeding for growth rate and sexual dimorphism [20]. It has already been evidenced that muscovy and mule ducks, but not Pekin ducks, are able to produce foie gras when overfed $[5,10]$. Up to now, there has been no investigation to study the genetic influences of meat characteristics in mule ducks, with the determination of additive, heterosis and maternal effects. In order to estimate these parameters, we carried out a crossbreeding experiment between muscovy and Pekin ducks.

\section{MATERIALS AND METHODS}

\subsection{Animals}

Ninety-nine ducks were studied. The factorial crossbreeding was set up in order to produce four genotypes: muscovy (MM, $\mathrm{n}=30$ ), Pekin (PP, $\mathrm{n}=23$ ), mule (MP, $\mathrm{n}=31$ ) and hinny (PM, $\mathrm{n}=15)$. Muscovy and Pekin female ducks were inseminated twice a week with pooled semen from either muscovy or Pekin drakes. The eggs were collected over a 6-week period and incubated in two successive batches taking into account the different durations of incubation for the four genotypes. After hatching, only male ducklings were raised at the INRA experimental farm on a floor pen. The number of hinny ducks was lower than expected due to fertility problems. Muscovy and Pekin ducks were raised separately whereas mule and hinny ducks were raised together. From 0 to 6 weeks of age, the ducks were given free access to a commercial pelleted diet. Between 6 and 11 weeks, the birds received increasing amounts of food, ranging from 210 to $380 \mathrm{~g}$ per day per bird. The composition of the feeding regimen was as follows: from 1 day to 4 weeks of age, $18.2 \%$ crude protein (CP) and $2830 \mathrm{kcal}$ metabolisable energy (ME) $\cdot \mathrm{kg}^{-1}$ and from 4 to 11 weeks of age, 
$16 \% \mathrm{CP}$ and $2850 \mathrm{kcal} \mathrm{ME} \cdot \mathrm{kg}^{-1}$. Between 11 and 13 weeks of age, the birds were prepared for overfeeding with graduated increasing amounts of feed [9]. During the overfeeding period (13th to 15 th week), the ducks were put into individual cages and were force-fed twice a day with a diet composed of whole grain corn, corn flour and water $(25,35$ and $40 \%$ respectively). During the overall overfeeding period, each genotype received a quantity of corn according to its body weight and its forcefeeding ability: $7952 \mathrm{~g}$ for Pekin ducks, $8143 \mathrm{~g}$ for muscovy ducks and $9995 \mathrm{~g}$ for both hybrid genotypes.

At 15 weeks of age, the birds were slaughtered in the experimental slaughterhouse: they were electrically stunned and bled by cutting the neck blood vessels. The present work was carried out in agreement with the French legislation on animal experimentation.

\subsection{Measurements}

\subsubsection{Growth and carcass traits}

All birds were weighed at the age of 6 weeks, 11 weeks (before overfeeding preparation), 13 weeks (before overfeeding) and 15 weeks of age (before slaughter). Five minutes after exsanguinations, a 1 g-muscle sample was removed from the right Pectoralis major (Pm) muscle and immediately crushed in a solution of sodium iodo-acetate $(5 \mathrm{mM} ; 1: 9, \mathrm{w} / \mathrm{v}$, [16]), before $\mathrm{pH}$ was measured with a glass electrode (Ingold, Mettler Toledo, Switzerland) and a portable $\mathrm{pH}$ meter. At the same time, temperature was also measured in the $\mathrm{Pm}$ muscle. At $20 \mathrm{~min}$ and $1 \mathrm{~h}$ post mortem, temperature and $\mathrm{pH}$ were directly measured in the right Pm using the same procedure. The liver was removed from the carcass and weighed. The foie gras yield was calculated as $100 \times$ foie gras weight/(body weight at 15 weeks - body weight at 13 weeks). After $24 \mathrm{~h}$ chilling at $4{ }^{\circ} \mathrm{C}$ in a ventilated room, the temperature and $\mathrm{pH}$ were measured in the right $\mathrm{Pm}$.

\subsubsection{Colour measurements}

The day after slaughtering the left breast muscle with skin (magret) was removed from the carcass. The magret was weighed. The colour was measured on the muscle and the internal part of the skin. The colour L* (lightness), a* (redness) and $b^{*}$ (yellowness) values were obtained with a Minolta chromameter (Minolta Camera, Osaka, Japan). The magret was then placed in a polystyrene tray, wrapped in an oxygen permeable film and stored at $4{ }^{\circ} \mathrm{C}$ for 9 days. At 9 days after slaughtering, the magret was weighed, and the colour was measured as described above.

\subsubsection{Biochemical measurements}

For biochemical evaluation, left Pm muscle samples were crushed in liquid nitrogen, freeze-dried and stored at $-20{ }^{\circ} \mathrm{C}$.

The dry matter was determined after $24 \mathrm{~h}$ at $103{ }^{\circ} \mathrm{C}$ [14]. The mineral content of the samples was determined after total calcinations in an oven at $550{ }^{\circ} \mathrm{C}$ [15]. The total lipid content was determined according to Folch et al. [8]. The total hydroxyproline content was determined after $\mathrm{HCl}$ hydrolysis of a lyophilised $300 \mathrm{mg}$ muscle sample [21], with subsequent hydroxyproline concentration analysed by spectrophotometry $\left(\lambda_{D O}=557 \mathrm{~nm}\right)$. The total quantity of collagen was estimated by multiplying the percentage of total hydroxyproline of the samples by 7.14. The thermo-soluble collagen was determined according to [12] after $60 \mathrm{~min}$ of heating at $77^{\circ} \mathrm{C}$.

The nitrogen content of the samples was determined according to AFNOR V18-120 (1997) using the FP 428 LECO (St-Joseph, MI, USA) analyser after total combustion 
of the samples and the results are expressed as total protein $(\mathrm{N} \times 6.25)$.

\subsubsection{Textural measurements}

At 9 days post mortem, the central part of the magret was cut. The samples were oriented according to the longitudinal fibre axis and frozen in isopentane cooled by liquid nitrogen and stored at $-80{ }^{\circ} \mathrm{C}$ until analysis.

The whole samples were thawed at $4{ }^{\circ} \mathrm{C}$ during an overnight period. A sample of this muscle was weighed, individually bagged and cooked in an $85{ }^{\circ} \mathrm{C}$ water bath to reach a central end-point temperature of $75^{\circ} \mathrm{C}$ [13]. The samples were rapidly wiped and weighed again to determine the cooking losses: cooking loss $(\%)=100 \times$ (initial weight - cooked weight)/initial weight. The objective texture (Warner-Bratzler test) of the raw and cooked meat was determined using a Warner-Bratzler single blade shear placed on a universal testing machine (MTS Synergie 200 - MTS Systems, Ivry-sur-Seine, France). Adjacent $1.0 \mathrm{~cm}$ wide and $3 \mathrm{~cm}$ long strips were cut from the medial portion of the muscle, parallel to the longitudinal axis of the myofibres and sheared according to the procedure described by [13]. The muscle was cut perpendicular to the muscle fibre orientation. The parameters from the force deformation curve were the maximal shear force (Fm, in N), the energy at the maxima (Energy $\mathrm{m}$ ), and total energy (Energy tot, $\mathrm{mJ}$ ) defined as the area under the force displacement curve.

A second test (Allo-Kramer test) was performed on a raw and a cooked sample of known thickness with a $1 \mathrm{~cm}^{2}$ area cylinder following a bicyclical compression at $80 \%$ sample thickness [17]. The parameters from the deformation curve were the maximal force at the first ( Fml, in $\mathrm{N}$ ) and the second compression (Fm2), the total energy (Energy1 and Energy2, mJ) for each compression cycle, defined as the area under the force displacement curve and time required to reach the maximal force ( $\mathrm{t} 1$ and $\mathrm{t} 2$, in $\mathrm{s}$ ) for each compression cycle. The parameters were given a sensorial meaning: hardness as Fm1, cohesiveness as Energy1/Energy2, gumminess as Fm1 $\times$ Energy1/Energy2, springiness as $\mathrm{t} 2 / \mathrm{t} 1$, and chewiness as gumminess $\times$ springiness. These parameters are supposed to be related to organoleptic textural measurements:

Hardness: force needed to completely bite the sample with molars.

Cohesiveness: deformation before complete rupture of the sample.

Gumminess: in relation with the necessary energy to crush the sample before swallowing.

Springiness: degree to which the sample returns to its original state after compression between the tongue and palate.

Chewiness: necessary energy to chew the sample before swallowing.

\subsection{Statistical analyses}

The traits were analysed using the GLM procedure of SAS [19]. The model included the effect of series (2 levels) and genotype (4 levels). The interaction between the two effects was first tested then removed from the model as non significant. The means were estimated for each genotype by the least squares method. Genetic parameters were estimated according to Dickerson [6]. The significance of the following contrasts was tested:

Additive effect $=0.5(\mathrm{MM}+\mathrm{MP}-\mathrm{PM}-\mathrm{PP})$ where MM was the lsmeans for muscovy ducks, PP the lsmeans for Pekin ducks and PM and MP the lsmeans for the hinny and mule ducks, respectively;

Heterosis $=0.5$ (MP+PM-MM-PP); Maternal effect $=0.5(\mathrm{PM}-\mathrm{MP})$. 
Table I. Lsmeans for growth traits and overfeeding traits, Means Square Error (MSE), and genetic effects.

\begin{tabular}{lcccccccc}
\hline & MM $^{1}$ & PM & MP & PP & MSE & Additive & Heterosis & Maternal \\
\hline Body weights (g) & & & & & & & & \\
6 weeks & $2785 \mathrm{a}$ & $2470 \mathrm{~b}$ & $2353 \mathrm{~b}$ & $1835 \mathrm{c}$ & 167 & $417^{*}$ & $101^{*}$ & $59^{*}$ \\
11 weeks & $4366 \mathrm{a}$ & $3527 \mathrm{~b}$ & $3442 \mathrm{~b}$ & $2508 \mathrm{c}$ & 272 & $886^{*}$ & 48 & 43 \\
13 weeks & $4837 \mathrm{a}$ & $3849 \mathrm{~b}$ & $3719 \mathrm{~b}$ & $2645 \mathrm{c}$ & 290 & $1032^{*}$ & 43 & 65 \\
15 weeks & $6520 \mathrm{a}$ & $5714 \mathrm{~b}$ & $5774 \mathrm{~b}$ & $4095 \mathrm{c}$ & 292 & $1243^{*}$ & $437 *$ & -30 \\
Foie gras weight (g) & $495 \mathrm{~b}$ & $493 \mathrm{~b}$ & $588 \mathrm{a}$ & $286 \mathrm{c}$ & 85 & $152^{*}$ & $150^{*}$ & $-48^{*}$ \\
Overfeeding weight gain (g) & $1683 \mathrm{c}$ & $1865 \mathrm{~b}$ & $2052 \mathrm{a}$ & $1450 \mathrm{~d}$ & 189 & $210^{*}$ & $392^{*}$ & $-93^{*}$ \\
\hline
\end{tabular}

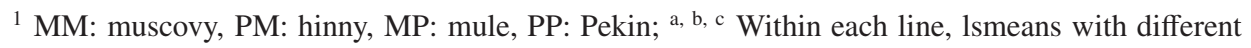
superscript letters are significantly different $(P \leq 0.05)$ for the effect of genotype. *: $P \leq 0.05$.

\section{RESULTS AND DISCUSSION}

\subsection{Growth and overfeeding traits}

At 6 weeks of age, the MM ducks were the heaviest, the PP ducks were the lightest and the two crossbred were intermediary (Tab. I). This hierarchy was maintained until slaughtering. However, the weight gain during overfeeding was higher for the two crossbreds, in relation to the amount of food distributed that differed from one genotype to another. Similarly, the foie gras weight was the lowest in PP ducks. For this trait, the mule duck foie gras weight was significantly higher than the foie gras weight of the hinny ducks. Olver et al. [18] showed that until the age of 10 weeks, Pekin ducks and mule ducks are heavier than the two other genotypes. Moreover, at the age of 7 weeks, hinny ducks are also heavier than muscovy ducks, which is in accordance with the late development of these latter animals [10]. Olver et al. [18] also evidenced that Pekin ducks are significantly fattier than the three other genotypes. Taï and Rouvier [20] showed that at a young age, muscovy ducks are lighter, Tsayia ducks are the heaviest, hinny are intermediary and mule ducks are at the same level as Tsayia ducks. At later ages (10 weeks), muscovy ducks are the heaviest, with the two crossbreds being intermediary.

For all growth and overfeeding traits, additive affects were largely positive and significant, showing the positive impact of muscovy genes, especially for weight at 15 weeks of age with a difference between muscovy and Pekin additive effects reaching four phenotypic standard errors. Heterosis effects were significant for body weight at 6 weeks of age, and for overfeeding traits represented by body weight at 15 weeks, foie gras weight and overfeeding weight gain. Maternal effects were of lower magnitude and only significant at the 0.05 level for body weight at 6 weeks of age, foie gras weight and overfeeding weight gain. Taï and Rouvier [20] found that the direct effects from muscovy are significant without heterosis or maternal effects on growth traits measured before 10 weeks of age. The high muscovy additive effect might be explained in the present study by the genetic origin of the strains [2]: the muscovy strain was originally created by crossbreeding muscovy lines selected for growth and overfeeding ability whereas the Pekin strain resulted from crossbreeding lines selected on reproduction traits. In general, growth traits are lowly affected by heterosis effects but during overfeeding, ingestion and liver metabolism are more 
Table II. Lsmeans for colour traits, temperature and $\mathrm{pH}$ measured on the magret, Means Square Error (MSE), and genetic effects.

\begin{tabular}{lccccccccc}
\hline Localisation & & MM $^{1}$ & PM & MP & PP & MSE & Additive & Heterosis & Maternal \\
\hline Skin 1 day & $\mathrm{L}^{*}$ & 72.8 & 73.7 & 72.9 & 71.9 & 2.4 & 0.02 & 0.93 & 0.40 \\
& $\mathrm{a}^{*}$ & $2.06 \mathrm{~b}$ & $1.72 \mathrm{~b}$ & $1.96 \mathrm{~b}$ & $2.89 \mathrm{a}$ & 1.3 & -0.30 & $-0.64^{*}$ & -0.12 \\
& $\mathrm{~b}^{*}$ & $20.8 \mathrm{a}$ & $18.6 \mathrm{ab}$ & $18.9 \mathrm{ab}$ & $16.2 \mathrm{~b}$ & 3.4 & $2.40^{*}$ & 0.25 & -0.14 \\
Skin 9 days & $\mathrm{L}^{*}$ & $76.76 \mathrm{a}$ & $76.7 \mathrm{a}$ & $76.9 \mathrm{a}$ & $75.1 \mathrm{~b}$ & 1.9 & $0.90^{*}$ & $0.82^{*}$ & -0.09 \\
& $\mathrm{a}^{*}$ & 2.63 & 2.53 & 2.39 & 2.97 & 1.3 & -0.24 & -0.34 & 0.07 \\
& $\mathrm{~b}^{*}$ & $19.7 \mathrm{a}$ & $15.8 \mathrm{~b}$ & $16.6 \mathrm{~b}$ & $14.8 \mathrm{~b}$ & 2.6 & $2.86^{*}$ & -1.00 & -0.40 \\
Muscle 1 day & $\mathrm{L}^{*}$ & $46.0 \mathrm{a}$ & $42.9 \mathrm{~b}$ & $44.2 \mathrm{ab}$ & $44.9 \mathrm{ab}$ & 2.3 & $1.17^{*}$ & $-1.92^{*}$ & -0.66 \\
& $\mathrm{a}^{*}$ & 21.1 & 21.2 & 21.5 & 21.4 & 1.1 & -0.03 & 0.07 & -0.12 \\
& $\mathrm{~b}^{*}$ & 8.97 & 8.14 & 9.05 & 9.28 & 1.5 & 0.30 & -0.53 & -0.46 \\
Muscle 9 days & $\mathrm{L}^{*}$ & $44.6 \mathrm{a}$ & $41.7 \mathrm{~b}$ & $42.5 \mathrm{ab}$ & $43.3 \mathrm{ab}$ & 2.1 & $1.05^{*}$ & $-1.81^{*}$ & -0.41 \\
& $\mathrm{a}^{*}$ & $14.6 \mathrm{~b}$ & $16.7 \mathrm{ab}$ & $16.1 \mathrm{ab}$ & $17.6 \mathrm{a}$ & 2.3 & $-1.81^{*}$ & 0.35 & 0.30 \\
\multirow{5}{*}{ Temperature } & $\mathrm{b}^{*}$ & $9.44 \mathrm{~b}$ & $9.17 \mathrm{~b}$ & $9.59 \mathrm{~b}$ & $11.23 \mathrm{a}$ & 0.9 & $-0.68^{*}$ & $-0.95^{*}$ & -0.21 \\
& $5 \mathrm{~min}$ & 43.35 & 43.53 & 43.30 & 43.07 & 0.75 & 0.03 & 0.20 & 0.11 \\
& $20 \mathrm{~min}$ & $43.89 \mathrm{a}$ & $44.74 \mathrm{~b}$ & $44.17 \mathrm{ab}$ & $43.76 \mathrm{a}$ & 0.89 & -0.22 & $0.63 *$ & $0.29 *$ \\
& $1 \mathrm{~h}$ & $36.7 \mathrm{a}$ & $36.7 \mathrm{a}$ & $35.9 \mathrm{a}$ & $34.1 \mathrm{~b}$ & 2.04 & $0.88^{*}$ & $0.90^{*}$ & 0.38 \\
pH & $24 \mathrm{~h}$ & 5.94 & 6.06 & 6.15 & 6.73 & 1.17 & -0.35 & -0.23 & -0.05 \\
& $5 \mathrm{~min}$ & 6.27 & 6.33 & 6.29 & 6.35 & 0.12 & $-0.06^{*}$ & -0.01 & 0.02 \\
& $20 \mathrm{~min}$ & 5.85 & 5.93 & 5.86 & 5.95 & 0.16 & $-0.09^{*}$ & -0.01 & 0.04 \\
& $1 \mathrm{~h}$ & 5.76 & 5.73 & 5.71 & 5.76 & 0.09 & $-0.04^{*}$ & -0.01 & 0.01 \\
& $24 \mathrm{~h}$ & 5.79 & 5.84 & 5.80 & 5.81 & 0.06 & $-0.03^{*}$ & 0.02 & 0.02 \\
\hline
\end{tabular}

${ }^{1}$ MM: muscovy, PM: hinny, MP: mule, PP: Pekin; ${ }^{\text {a, b, c }}$ Within each line, lsmeans with different superscript letters are significantly different $(P \leq 0.05)$ for the effect of genotype. *: $P \leq 0.05$.

involved than growth potential. The higher overfeeding ability of the crossbred genotype was mainly explained by a higher feed consumption. On that point, the results obtained in the present study confirmed previous results observed on overfed ducks $[4,9,10]$ but also on non overfed ducks [4]. When the amount of corn is distributed according to their body weight, muscovy ducks exhibit a higher foie gras production [5]. The high feed consumption of crossbred ducks compared with their parental genotypes remains to be explained.

\subsection{Temperature, $\mathrm{pH}$ and colour}

For $\mathrm{pH}$ and temperature parameters, there were very small differences between the four genotypes (Tab. II). The only significant differences were found for the temperature measured 20 minutes post mortem for which the PM ducks had a higher value than purebred ducks and temperature measured one hour post mortem, for which PP ducks had the lowest value. At 20 minutes post mortem, the elevation of temperature resulted from the hot water bath for defeathering. No explanation could be found for the differences between PM and MM or PP ducks for the differences in body temperature at 20 minutes post mortem. The faster decrease observed at one hour post mortem in the PP duck carcass might be expected from their lowest weight in comparison with the other genotypes. No similar pattern could be observed for crossbred 
ducks, though they were also lighter than MM ducks. At $24 \mathrm{~h}$ post mortem all the carcasses were at cold room temperature.

Significant differences were observed for colour traits on muscle and skin. The PP ducks had the darkest skin (low L*) but the difference with the three other genotypes was only significant when measured at 9 days post mortem. PP ducks also had high $\mathrm{a}^{*}$ value for skin, the difference with MM, MP and PM ducks being significant at 1 day post mortem, and a low $b^{*}$ value, the difference with MM ducks being significant both at 1 and 9 days post mortem. The PP skin should appear darker, redder and less yellow tainted. The crossbred ducks had similar values as MM ducks, except for $b^{*}$ value measured at 1 days for which they were intermediate and at 9 days post mortem for which they had similar values as PP ducks. For breast meat, the PM ducks had the darkest meat and the MM ducks had the lightest meat at 1 and 9 days post mortem. The two other genotypes were intermediate, but not significantly different from MM or PM ducks. For $a^{*}$ and $b^{*}$, the only significant differences could be found at 9 days post mortem between PP and MM for $\mathrm{a}^{*}$ with a significant increase of redness in PP ducks, and between PP and the three other genotypes for $\mathrm{b}^{*}$, with an increase of yellowness in PP ducks. Fernandez et al. [7] previously observed that heavier breast muscles were lighter and had greater $a^{*}$ and $b^{*}$ values, and it could be hypothesised that a great muscle development could induce a dilution of heminic pigments (myoglobin and haemoglobin). In the present study, this hypothesis was not confirmed, because the lightest weight genotype (PP) was not the darkest meat (PM). The enhancement of differences between genotypes from 1 to 9 days post mortem could be related to differences in the maturation process, but this point remains to be studied. Previous comparisons between meats of different genotypes showed a higher ultimate $\mathrm{pH}$ value in muscovy ducks in com- parison with Pekin ducks [1]. These results were not confirmed in the present study because all the genotypes had an ultimate $\mathrm{pH}$ value at the same level. There was no available study on $\mathrm{pH}$ decrease simultaneously compared in different duck genotypes. In mule ducks, Fernandez et al. [7] showed that an increased rate of post mortem fall was associated with a paler colour of duck magrets. In the present study, since no differences could be found between the four genotypes for $\mathrm{pH}$ measured at 20 minutes post mortem, the darker colour of PM meat could only be related to its higher temperature at 20 minutes post mortem.

For skin colour, genetic effects were not consistent through stocking duration, but it can be said that muscovy genes induced a more yellow skin both at 1 and 9 days post mortem. A small positive heterosis was found for $\mathrm{L}^{*}$ values, non significant at 1 day post mortem and significant at 9 days post mortem. For meat colour, direct effects were found significant for $\mathrm{L}^{*}$, and for $\mathrm{a}^{*}$ and $\mathrm{b}^{*}$ but at 9 days post mortem only. Muscovy genes induced a lighter meat and, at 9 days only, a less red and yellow meat. A negative heterosis was observed for the $\mathrm{b}^{*}$ value at 9 days post mortem and for $\mathrm{L}^{*}$ values at 1 and 9 days post mortem. This negative heterosis could be interesting for mule duck meat production. Fernandez et al. [7] reported a noticeable percentage of muscles with a marked alteration of colour with a very pale appearance in mule ducks, but it should be influenced by favourable heterosis effects. Improving meat colour by decreasing $L^{*}$ value by selection should be efficient in addition to heterosis effects. For $\mathrm{pH}$ values, only direct effects were significant, with muscovy genes decreasing $\mathrm{pH}$ values. These significant direct effects were unexpected considering that no differences were observed between genotypes. Improving $\mathrm{pH}$ value when needed should not be difficult considering the non significant heterosis and maternal effects. Maternal effects 
Table III. Lsmeans for biochemical measurements, Means Square Error (MSE), and genetic effects.

\begin{tabular}{|c|c|c|c|c|c|c|c|c|}
\hline & $\mathrm{MM}^{1}$ & PM & MP & PP & MSE & Additive & Heterosis & Maternal \\
\hline Cooking loss (\%) & $24.57 \mathrm{a}$ & $21.09 \mathrm{~b}$ & $19.43 b$ & $20.63 b$ & 3.0 & 1.1 & $-2.3 *$ & 0.8 \\
\hline Dry matter $(\%)$ & 28.29 & 27.51 & 27.82 & 28.07 & 1.42 & 0.27 & -0.51 & -0.16 \\
\hline Mineral content $(\%)$ & 1.23 & 1.20 & 1.16 & 1.15 & 0.08 & 0.01 & -0.01 & 0.02 \\
\hline Lipid content (\%) & $4.91 b$ & $5.34 \mathrm{ab}$ & $5.81 \mathrm{ab}$ & $6.30 \mathrm{a}$ & 1.03 & -0.42 & 0 & -0.27 \\
\hline Protein content $(\%)$ & $22.93 \mathrm{a}$ & $21.96 b$ & $21.68 b$ & $21.31 b$ & 0.86 & $0.67 *$ & -0.31 & 0.14 \\
\hline Total Collagen $\left(\mathrm{mg} \cdot \mathrm{g}^{-1}\right)$ & $4.82 \mathrm{a}$ & $4.38 \mathrm{ab}$ & $4.45 \mathrm{a}$ & $4.30 \mathrm{~b}$ & 0.60 & $0.30^{*}$ & -0.15 & -0.04 \\
\hline Thermosoluble collagen $\left(\mathrm{mg} \cdot \mathrm{g}^{-1}\right)$ & $0.632 b$ & $0.548 \mathrm{~b} \mathrm{c}$ & $0.637 \mathrm{ab}$ & $0.815 \mathrm{a}$ & 0.20 & -0.05 & $-0.13^{*}$ & -0.04 \\
\hline Collagen Solubility (\%) & $12.99 \mathrm{~b}$ & $12.77 \mathrm{~b} 1$ & $14.27 \mathrm{ab}$ & $18.86 \mathrm{a}$ & 3.6 & $-2.2^{*}$ & $-2.4^{*}$ & -0.8 \\
\hline
\end{tabular}

${ }^{1}$ MM: muscovy, PM: hinny, MP: mule, PP: Pekin; ${ }^{a, b, c}$ Within each line, lsmeans with different superscript letters are significantly different $(P \leq 0.05)$ for the effect of genotype.*: $P \leq 0.05$.

never appeared to be significant except for the temperature measured 20 minutes post mortem.

\subsection{Biochemical measurements}

There were no significant differences between the four genotypes for dry matter and mineral percentage (Tab. III). Significant differences were observed for the other biochemical traits. For thermosoluble collagen contents, PM and MM ducks were at the same low level, with MP ducks being intermediary, and PP ducks at the highest level. For total collagen, MM and MP were at the same high level, PM being intermediate and PP being with the lowest quantity. Thus, collagen solubility was the highest for PP ducks in comparison with $\mathrm{MM}$ and PM ducks, with MP being intermediate. For cooking loss and protein content, MM ducks were different from the three other genotypes. Lipid content was the highest for PP ducks, the lowest for MM ducks while crossbred ducks were intermediate, which has been previously shown in overfed as well as in nonoverfed ducks $[3,9,11]$.

The additive effects were significant for protein content, as well as for total colla- gen and soluble collagen content, but with a positive effect on total collagen and a negative effect on collagen solubility for muscovy genes. Heterosis effects were significant for cooking loss, thermosoluble collagen and collagen solubility, with a negative sign. Interestingly, the negative heterosis effect on cooking loss could be related to the negative heterosis effect on lightness, since darker meat could be expected to have lower losses. The differences between genotypes for lipid content could not be associated with significant genetic effects and could result from the combination of small direct and maternal effects. In Baéza et al. [3], larger differences between MM and PP were reported, and could be related to additive effects, because they used a different particularly lean muscovy line.

\subsection{Textural traits}

For all traits, except gumminess and springiness measured on raw meat, MM ducks were significantly different from PP ducks (Tab. IV). The meat was more firm more chewy, gummy, springy and less cohesive. The crossbred ducks were at the same level as the PP duck (hardness and 
Table IV. Lsmeans for magret textural measurements on raw and cooked meat, Means Square Error (MSE), and genetic effects.

\begin{tabular}{lcccccccc}
\hline & MM $^{1}$ & PM & MP & PP & MSE & Additive & Heterosis & Maternal \\
\hline Raw meat & & & & & & & & \\
Hallo Kramer test & & & & & & & & \\
Hardness & $82 \mathrm{a}$ & $58 \mathrm{~b}$ & $57 \mathrm{~b}$ & $54 \mathrm{~b}$ & 23 & $14^{*}$ & $-10^{*}$ & 1 \\
Chewiness & $414 \mathrm{a}$ & $322 \mathrm{~b}$ & $298 \mathrm{~b}$ & $309 \mathrm{~b}$ & 158 & 41 & -51 & 12 \\
Cohesiveness & $4.76 \mathrm{~b}$ & $5.33 \mathrm{ab}$ & $5.00 \mathrm{ab}$ & $5.70 \mathrm{a}$ & 1.24 & $-0.63^{*}$ & -0.06 & 0.16 \\
Gumminess & $414 \mathrm{a}$ & $322 \mathrm{ab}$ & $298 \mathrm{~b}$ & $309 \mathrm{ab}$ & 158 & 41 & -51 & 12 \\
$\quad$ Springiness & 5.20 & 4.14 & 3.62 & 3.63 & 3.09 & 0.53 & -0.54 & 0.26 \\
Warner-Bratzler test & & & & & & & & \\
Force max & $43 \mathrm{a}$ & $37 \mathrm{ab}$ & $23 \mathrm{~b}$ & $19 \mathrm{~b}$ & 13 & 5 & -1 & $7^{*}$ \\
Energy at max & $277 \mathrm{a}$ & $220 \mathrm{ab}$ & $129 \mathrm{~b}$ & $112 \mathrm{~b}$ & 97 & 37 & -20 & $46^{*}$ \\
Cooked meat & & & & & & & & \\
Hallo Kramer test & & & & & & & & \\
Hardness & $103 \mathrm{a}$ & $81 \mathrm{~b}$ & $73 \mathrm{~b}$ & $66 \mathrm{~b}$ & 18 & $14^{*}$ & -7 & 4 \\
Chewiness & $265 \mathrm{a}$ & $217 \mathrm{~b}$ & $202 \mathrm{~b}$ & $188 \mathrm{~b}$ & 54 & $31^{*}$ & -17 & 8 \\
Cohesiveness & $2.56 \mathrm{~b}$ & $2.68 \mathrm{ab}$ & $2.73 \mathrm{ab}$ & $2.81 \mathrm{a}$ & 0.21 & -0.10 & 0.02 & -0.03 \\
Gumminess & $265 \mathrm{a}$ & $217 \mathrm{~b}$ & $202 \mathrm{~b}$ & $188 \mathrm{~b}$ & 54 & 31 & -17 & 8 \\
Springiness & $4.18 \mathrm{a}$ & $3.35 \mathrm{ab}$ & $3.22 \mathrm{ab}$ & $2.45 \mathrm{~b}$ & 1.14 & $0.80^{*}$ & -0.03 & 0.06 \\
Warner-Bratzler test & & & & & & & & \\
Force max & $62.6 \mathrm{a}$ & $46.0 \mathrm{ab}$ & $46.6 \mathrm{ab}$ & $33.2 \mathrm{~b}$ & 9.6 & $15.0^{*}$ & -1.6 & -0.3 \\
Energy at max & $220 \mathrm{a}$ & $160 \mathrm{ab}$ & $160 \mathrm{ab}$ & $107 \mathrm{~b}$ & 41 & $57^{*}$ & -4 & 0 \\
\hline
\end{tabular}

${ }^{1}$ MM: muscovy, PM: hinny, MP: mule, PP: Pekin; ${ }^{a, b, c}$ Within each generation, lsmeans with different superscript letters are significantly different $(P \leq 0.05)$ for the effect of genotype.

$*: P \leq 0.05$.

chewiness) or intermediary (cohesiveness and springiness for cooked meat only). For shear measurements, on raw meat, MP ducks were similar to PP ducks, and MM ducks showed a more resistant meat. On cooked samples, the values observed on crossbred ducks were intermediate between the two other genotypes. The tenderness of PP meat could be explained by the lower collagen content and the higher collagen solubility content, as well as the low cooking loss. Though crossbred ducks had similar collagen properties to MM ducks, their sensory properties were more similar to PP ducks than to MM ducks for hardness and chewiness.
On raw meat, the direct effects were significant for hardness and cohesiveness. Maternal effects were significant on shear measurements, with the dam muscovy duck inducing a harder meat. On cooked meat, direct effects from muscovy ducks induced a more firm meat. No heterosis or maternal effects were found significant. For raw meat, it is difficult to conclude on a genetic influence considering the few significant parameters. On cooked meat, the differences between genotypes were mainly explained by additive effects, which could result from the strain effect. Baéza et al. [3] reported results on textural comparison between the four genotypes, 
with no significant differences for shear force value. Thus, muscle was sampled one day post mortem, not 9 days as in the present study. Thus, differences in textural properties between MM and PP ducks might be related to the maturation process.

\section{CONCLUSION}

Important differences between the genetic type for overfeeding and meat characteristics were measured. These differences were partially under genetic influences, with a very high heterosis effect for foie gras weight. For most of the meat traits, crossbred ducks could be considered as intermediate between their parental breeds or at the same level of one of their parental breed. No major meat problems have been reported until now for overfed mule duck meat. In the present study, meat colour or texture exhibited influences of additive effects. However, in order to improve meat characteristics in mule ducks, genetic variability remains to be determined in each parental breed.

\section{ACKNOWLEDGEMENTS}

This project was supported by the région Midi-Pyrénées. We cordially wish to thank the staff of the UEPFG, which took part in the realisation of this experimentation for their technical contribution, as well as the staff of the ENSAT and SAGA that contributed to the measurements.

\section{REFERENCES}

[1] Baéza E., Structural, chemical and technological characteristics of Muscovy, Pekin and mule duck meat, Proceedings of the Symposium on Scientific cooperation in Agriculture between INRA and COA, Toulouse, France, 1999, pp. 105-116.
[2] Baéza E., Dessay C., Wacrenier N., Marche G., Listrat A., Effect of selection for improved body weight and composition on muscle and meat characteristics in Muscovy duck, Brit. Poultry Sci. 43 (2002) 560-568.

[3] Baéza E., Rideau N., Chartrin P., Davail S., Hoo-Paris R., Mourot J., Guy G., Bernadet M.D., Hermier D., Canards de Barbarie, Pékin et leurs croisements : aptitude à l'engraissement, INRA Prod. Anim. 18 (2005) 131-141.

[4] Chartrin P., Mourot J., Bernadet M.D., Guy G., Duclos M.J., Baéza E., Effect of genotype and force-feeding on the intramuscular fat deposition in duck, Proceedings of the XVIth European Symposium on the quality of poultry meat, St Brieuc, France, 2003, pp. 224-230.

[5] Davail S., Rideau N., Guy G., André J.M., Hermier D., Hoo-Paris R., Hormonal and metabolic responses to overfeeding in three genotypes of ducks, Comp. Biochem. Phys. A 134 (2003) 707-715.

[6] Dickerson G., Experimental approaches in utilizing breed resources, Anim. Breed. Abstr. 37 (1969) 191-202.

[7] Fernandez X., Auvergne A., Renerre M., Gatellier P., Manse H., Babilé R., Preliminary observations on the colour variability of breast meat ('magrets') in force-fed ducks, Anim. Res. 52 (2003) $567-574$.

[8] Folch J., Lees M., Stanley G.H.S., A simple method for the isolation and purification of total lipids from animal tissues, J. Biol. Chem. 226 (1957) 497-509.

[9] Guy G., Rousselot-Pailley D., Gourichon D., Comparaison des performances de l'oie, du canard mulard et du canard de Barbarie soumis au gavage, Ann. Zootech. 44 (1995) 297-305.

[10] Guy G., Hermier D., Davail S., Bely M., André J.M., Hoo-Paris R., Meat production and force-feeding ability of different types of ducks, Proceedings of the 1st World Waterfowl Conference, Taichung, Taïwan, 1999.

[11] Hermier D., Guy G., Guillaumin S., Davail S., André J.M., Hoo-Paris R., Differential channelling of liver lipids in relation to susceptibility to hepatic steatosis in two species of ducks, Comp. Biochem. Phys. B 135 (2003) 663-675. 
[12] Hill F., The solubility of intramuscular collagen in meat animals of various ages, J. Food Sci. 31 (1966) 161-166.

[13] Honikel K.O., Reference methods for the assessment of physical characteristics of meat, Meat Sci. 49 (1998) 447-457.

[14] J.O.C.E., Dosage de l'humidité, J. O. Comm. Eur. 1971, L279/8, 1971.

[15] J.O.C.E., Dosage des cendres brutes, J. O. Comm. Eur. 1971, L155/20, 1971.

[16] Jeacoke R., Continuous measurements of the $\mathrm{pH}$ of beef muscle in intact beef carcasses, J. Food Techn. 12 (1977) 375-386.

[17] Meullenet J.F.C., Carpenter J.A., Lyon B.G., Lyon C.E., Bi-cyclical instrument for assessing texture profile parameters and its relationship to sensory evaluation of texture, J. Texture Stud. 28 (1997) 101-118.

[18] Olver M.D., Du Perez J.J., Kuyper A., Mould D., The carcass composition and growth of the mule duckling compared to purebred ducklings, Agroanimalia 9 (1977) 7-12.

[19] SAS, SAS Institute Inc., SAS OnlineDoc®), Version 8, Cary, NC, USA, 1999.

[20] Tai C., Rouvier R., Crossbreeding effect on sexual dimorphism of body weight in intergeneric hybrids obtained between muscovy and Pekin duck, Genet. Sel. Evol. 30 (1998) 163-170.

[21] Woessner J.F. Jr., The determination of hydroxyproline in tissue and protein samples containing small proportions of this amino acid, Arch. Biochem. Biophys. 93 (1961) 440-447. 
